Article

\title{
Preparation and Reaction Mechanism Characterization of Alkali-activated Coal Gangue-Slag Materials
}

\author{
Hongqiang Ma ${ }^{\circledR}$, Hongguang Zhu *, Cheng Yi, Jingchong Fan, Hongyu Chen, Xiaonan Xu and \\ Tao Wang \\ School of Mechanics and Civil Engineering, China University of Mining and Technology (Beijing), \\ Beijing 100083, China \\ * Correspondence: zhg@cumtb.edu.cn
}

Received: 7 June 2019; Accepted: 10 July 2019; Published: 12 July 2019

\begin{abstract}
In this paper, slag is used as a calcium source to make alkali-activated coal gangue-slag (AACGS) based material. The reaction mechanism of AACGS materials was discussed in depth by means of XRD, FT-IR, ${ }^{29}$ Si MAS-NMR (nuclear magnetic resonance) and SEM-EDS (energy dispersive spectrometer). The experimental results show that coal gangue can be used as a raw material for preparing alkali-activated materials. The liquid-solid ratio is the most influential factor on AACGS paste fluidity and strength, followed by slag content. As the modulus of sodium hydroxide increases, the depolymerization process of the reactant precursor is accelerated, but the high sodium hydroxide concentration inhibits the occurrence of the early coal gangue-slag polycondensation reaction, and exerts little effect on the $28 \mathrm{~d}$ compressive strength. $\mathrm{Ca}^{2+}$ in the slag promotes exchange with $\mathrm{Na}^{+}$, and the product is converted from N-A-S-H gel to C-(A)-S-H gel, and C-(A)-S-H is formed with higher $\mathrm{Ca} / \mathrm{Si}$ ratio with the increase of slag content. The slight replacement of coal gangue by slag can greatly improve the reaction process and the strength of AACGS materials.
\end{abstract}

Keywords: alkali-activated coal gangue-slag; paste fluidity; cement paste fluidity; compressive strength; polycondensation reaction

\section{Introduction}

Cement is one of the world's most widely used construction cementitious materials. About 1.6 billion tons of cement is used each year, releasing 1.5 billion tons of $\mathrm{CO}_{2}$, and about $5 \%$ to $8 \%$ of global $\mathrm{CO}_{2}$ emissions are caused by cement [1-4]. It has become crucial to develop new, sustainable and low-carbon construction materials with the advent of low-carbon economy. Among the numerous alternatives available, alkali-activated materials have aroused widespread concern, since they can be used as a $100 \%$ replacement to cement and significantly reduce the emission of $\mathrm{CO}_{2}$ and dust particles [5]. Alkali-activated materials are characterized by high initial strength, low hydration heat, freezing resistance, chemical resistance, strong durability and excellent high-temperature stability [6-10]. The alkali-activated materials can be considered as the best replacements for cement based on these advantages [11].

Alkali-activated materials are products of the reactions between alumino-silicate materials (fly ash, slag, metakaolin, coal gangue, ceramic, etc.) and alkaline solutions at ambient temperature [11,12]. All materials rich in active silicon-aluminum oxides (slag, fly ash, metakaolin, coal gangue, etc.) can undergo polymerization reactions with high-concentration alkalis [13]. However, the reaction products of alkali-activated slag (rich in $\mathrm{CaO}$ ) are different from those of alkali-activated metakaolin, coal gangue or fly ash (rich in Si and Al) the former are C-(A)-S-H gels while the latter are N-A-S-H gels [14,15], 
the structure of which is influenced by alkali concentration and Si/Al molar ratio [16]. So far, studies on alkali-activated materials have been primarily focused on commonly used supplementary cementitious materials such as metakaolin, slag and fly ash.

Coal gangue is the solid waste produced in coal mining. In countries with developed coal resources, such as China, India, Australia, Germany, the United States and South Africa, the discharge of coal gangue waste remains high [17]. Waste storage generated from coal gangue has a high risk of environmental pollution [18]. The coal gangue crystalline mineral phase is resolved into $\mathrm{SiO}_{2}$ and $\mathrm{Al}_{2} \mathrm{O}_{3}$ components, which has intensive pozzolanic activities under high temperature $[19,20]$. Literatures on alkali-activated calcined coal gangue are deficient. Wan et al. [21] used $\mathrm{CaO}$ as the activator and calcined coal gangue, slag and gypsum to configure P.C 32.5 cementitious materials. Geng et al. [22] used red mud and coal gangue as raw materials to prepare binary geopolymers, the results show that the final product is composed of amorphous silica-aluminum base polymer gel and some impurity filler, which can be used as a new building material. Han et al. [23] prepared coal gangue-slag composite materials with sodium silicate as an activator, and found that the hydration products were mainly zeolite. The compressive strength of the composite system was greater than $40 \mathrm{MPa}$ when the content of calcined coal gangue was less than 30\%. Yi et al. [24] prepared coal gangue geopolymers with sodium hydroxide and sodium silicate as alkali activators, and found that coal gangue can be used as geopolymer raw material. However, compared with P.O 42.5 cement specimens, coal gangue geopolymers have higher $1 \mathrm{~d}$ compressive strength and lower $28 \mathrm{~d}$ compressive strength. However, Kumar et al. [25] significantly improved the low reactivity of alkali-activated fly ash by adding slag to fly ash. Therefore, the calcium source can be used as an important measure to improve the strength of alkali-activated materials.

In this paper, with silica-alumina coal gangue as the main material, slag as the calcium source, $\mathrm{NaOH}$ and $\mathrm{Na}_{2} \mathrm{SiO}_{3}$ to be the alkali activator, the AACGS materials is prepared. Evaluate the impacts of slag content $(0 \%, 10 \%, 20 \%, 30 \%, 40 \%$ and $50 \%), \mathrm{NaOH}$ molar concentration, $\mathrm{NaOH} / \mathrm{Na}_{2} \mathrm{SiO}_{3}$ mass ratio and liquid-solid ratio on AACGS paste fluidity, non-evaporable water dosage, compressive strength and microstructure (XRD, FT-IR, ${ }^{29}$ Si MAS-NMR(nuclear magnetic resonance) and SEM-EDS (energy dispersive spectrometer)) through experiments. In-depth analysis of the reaction mechanism of AACGS materials.

\section{Experimental}

\subsection{Raw Materials}

The Shanxi clay coal gangue powder selected was calcined with constant temperature in muff furnace $700{ }^{\circ} \mathrm{C}$ for $2 \mathrm{~h}$, the slag was the S95-grade granulated blast-furnace slag from Hebei Iron and Steel Company (Shijiazhuang, China). The $96 \%$ sodium hydroxide and a modulus of $3.22\left(26.5 \% \mathrm{SiO}_{2}\right.$, $8.5 \% \mathrm{Na}_{2} \mathrm{O}$ and $65 \% \mathrm{H}_{2} \mathrm{O}$ ) sodium silicate solution were used as the alkali activator.

The main chemical compositions of calcined coal gangue, S95-grade slag and cement are given in Table 1. It is obvious that calcined coal gangue belongs to the silica-alumina material, while slag belongs to the calcium-silica-alumina material. Figure 1 reveals the grain size distribution of coal gangue and slag, and the median particle size d50 values of coal gangue and slag were $17.252 \mu \mathrm{m}$ and $10.529 \mu \mathrm{m}$, respectively. 
Table 1. Chemical component of calcined coal gangue, slag and cement (mass fraction, \%).

\begin{tabular}{cccc}
\hline Parameters & Calcined Coal Gangue & Slag & Cement \\
\hline $\mathrm{SiO}_{2}$ & 56.56 & 30.58 & 20.88 \\
$\mathrm{Al}_{2} \mathrm{O}_{3}$ & 36.78 & 14.04 & 5.57 \\
$\mathrm{CaO}$ & 0.62 & 38.43 & 62.09 \\
$\mathrm{Fe}_{2} \mathrm{O}_{3}$ & 1.95 & 0.35 & 2.40 \\
$\mathrm{MgO}$ & 0.22 & 10.57 & 2.43 \\
$\mathrm{Na}_{2} \mathrm{O}$ & 0.42 & 0.57 & 0.32 \\
$\mathrm{SO}_{3}$ & 0.03 & 2.36 & 5.02 \\
$\mathrm{TiO}_{2}$ & 2.10 & 1.93 & 0.31 \\
$\mathrm{LOI}$ & 1.32 & 1.17 & 0.98 \\
\hline
\end{tabular}

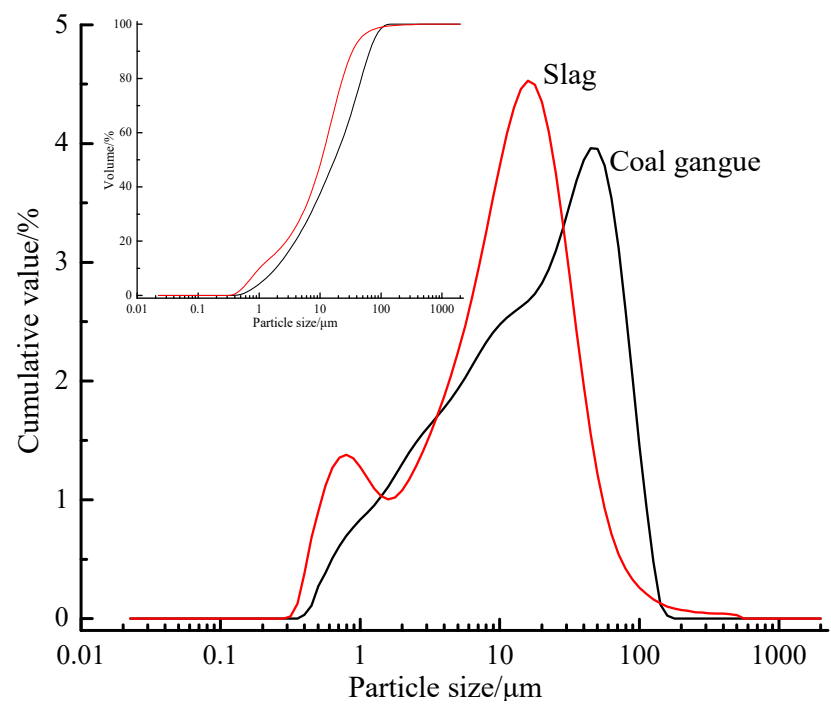

Figure 1. Calcined coal gangue and slag particle size analysis.

\subsection{Mixes Design and Specimens Preparation}

In this paper, the effects of slag content, $\mathrm{NH}$ molar concentration, liquid-solid ratio and $\mathrm{NaOH} / \mathrm{Na}_{2} \mathrm{SiO}_{3}$ mass ratio on AACGS materials were studied. The P.O 42.5 pure cement samples as a controlled sample, and the specific mixing ratio was displayed in Table 2, a total of 19 experiments were carried out. The slag content is $0 \%, 10 \%, 20 \%, 30 \%, 40 \%$ and $50 \%$ respectively; six kinds of liquid-solid ratio (liquid refers to the sum of all liquids in the mixed system, including the external addition of water, water in NS solution, and the $\mathrm{H}_{2} \mathrm{O}$ in $\mathrm{NH}$ solid. Solids refer to the sum of all solids in the mixed system, including coal gangue, fly ash, solids in $\mathrm{NS}$ solution and the mass of $\mathrm{Na}_{2} \mathrm{O}$ solids in $\mathrm{NH}$ solids) were selected, including $0.28,0.30,0.32,0.34,0.36$ and 0.38 ; five different molar concentrations of $\mathrm{NH}$ were selected, respectively $8 \mathrm{M}, 10 \mathrm{M}, 12 \mathrm{M}, 14 \mathrm{M}$ and $16 \mathrm{M}$; the mass ratios of $\mathrm{NaOH} / \mathrm{Na}_{2} \mathrm{SiO}_{3}$ were $1: 1$, 1:1 1.5, 1:2 and 1:2.5 respectively. Sample numbers such as S0-12M2-36, where S0 represents $0 \%$ of the slag content, 12 represents the $\mathrm{NaOH}$ molar concentration, $\mathrm{M} 2$ represents the $\mathrm{NaOH} / \mathrm{Na}_{2} \mathrm{SiO}_{3}$ mass ratio is 2 and 36 represents the liquid-solid ratio, which was 0.36 .

The alkali activator solution should be configured $24 \mathrm{~h}$ before use, and $\mathrm{NH}$ solutions with different $\mathrm{NH}$ modulus should be configured respectively. After cooling to room temperature, the NS solution was mixed with the NS solution according to the mass ratio in Table 2. After mixing coal gangue and slag powder evenly, the alkali activator was added and stirred with cement mixer for $5 \mathrm{~min}$, poured the fresh paste into steel molds quickly $(40 \mathrm{~mm} \times 40 \mathrm{~mm} \times 40 \mathrm{~mm})$ and vibrated them for $60 \mathrm{~s}$ on an electric vibration table to remove residual air. The molds were covered with thin polyethylene films and cured for 1 day at relative humidity $(\mathrm{RH})=95 \% \pm 1 \%$ and $\mathrm{T}=20 \pm 2{ }^{\circ} \mathrm{C}$. They were then demolded, transferred to standard curing rooms and cured for $3 \mathrm{~d}, 7 \mathrm{~d}$ and 28 days respectively. 
Table 2. Mix proportion of the alkali-activated coal gangue-slag (AACGS) paste.

\begin{tabular}{|c|c|c|c|c|c|}
\hline Samples & $\begin{array}{c}\text { Liquid-Solid } \\
\text { Ratio }\end{array}$ & $\begin{array}{c}\text { NaOH Molar } \\
\text { Concentration } \\
\text { (M) }\end{array}$ & $\begin{array}{c}\mathrm{NaOH} / \\
\mathrm{Na}_{2} \mathrm{SiO}_{3}{ }^{a}\end{array}$ & $\begin{array}{c}\text { Binder Coal } \\
\text { Gangue: Slag a }\end{array}$ & $\begin{array}{c}\text { Paste } \\
\text { Fluidity/mm }\end{array}$ \\
\hline Cement & 0.36 & - & - & - & 60.0 \\
\hline S0-12M2-36 & 0.36 & 12 & $1: 2$ & 100:0 & 138.0 \\
\hline S10-12M2-36 & 0.36 & 12 & $1: 2$ & $90: 10$ & 147.8 \\
\hline S20-12M2-36 & 0.36 & 12 & $1: 2$ & $80: 20$ & 150.8 \\
\hline S30-12M2-36 & 0.36 & 12 & $1: 2$ & $70: 30$ & 162.3 \\
\hline $\mathrm{S} 40-12 \mathrm{M} 2-36$ & 0.36 & 12 & $1: 2$ & $60: 40$ & 166.5 \\
\hline S50-12M2-36 & 0.36 & 12 & $1: 2$ & $50: 50$ & 170.5 \\
\hline S30-12M2-28 & 0.28 & 12 & $1: 2$ & $70: 30$ & 110.0 \\
\hline S30-12M2-30 & 0.30 & 12 & $1: 2$ & $70: 30$ & 122.0 \\
\hline S30-12M2-32 & 0.32 & 12 & $1: 2$ & $70: 30$ & 136.0 \\
\hline S30-12M2-34 & 0.34 & 12 & $1: 2$ & $70: 30$ & 146.0 \\
\hline S30-12M2-38 & 0.38 & 12 & $1: 2$ & $70: 30$ & 172.0 \\
\hline S30-8M2-36 & 0.36 & 8 & $1: 2$ & $70: 30$ & 160.8 \\
\hline S30-10M2-36 & 0.36 & 10 & $1: 2$ & $70: 30$ & 160.5 \\
\hline S30-14M2-36 & 0.36 & 14 & $1: 2$ & $70: 30$ & 157.3 \\
\hline S30-16M2-36 & 0.36 & 16 & $1: 2$ & $70: 30$ & 160.5 \\
\hline S30-8M1-36 & 0.36 & 8 & $1: 1$ & $70: 30$ & 155.0 \\
\hline S30-8M1.5-36 & 0.36 & 8 & 1:1.5 & $70: 30$ & 152.0 \\
\hline S30-8M2.5-36 & 0.36 & 8 & $1: 2.5$ & $70: 30$ & 163.0 \\
\hline
\end{tabular}

\subsection{Testing Methods}

\subsubsection{Samples Performance Testing}

(1) Paste fluidity: The paste fluidity of AACGS was measured by the standard net paste fluidity test model (upper diameter $\Phi=60 \mathrm{~mm}$; lower diameter $\Phi=36 \mathrm{~mm} ; \mathrm{H}=60 \mathrm{~mm}$ ) [24].

(2) Compressive strength: According to GB/T 17671-1999 compressive strength test standard, test and calculate the compressive strength value. A YAW-300 pressure testing machine (Beijing, China) was employed to test $1 \mathrm{~d}, 3 \mathrm{~d}, 7 \mathrm{~d}$ and $28 \mathrm{~d}$ compressive strength of the cube specimens of AACGS materials. The loading speed ranged from 0.5 to $0.8 \mathrm{MPa} / \mathrm{s}$. Three samples of each mixture proportion were tested, with the experimental values averaged to generate the test value for each mixture proportion. If the compressive strength value of one sample exceeded the median value by $15 \%$, the median value was taken as the compressive strength value of the samples.

(3) Non-evaporative water: Non-evaporative water content was measured by combustion method [24]. A certain amount of samples were dried at $105^{\circ} \mathrm{C}$ for $24 \mathrm{~h}$ and weighed. Then calcining at $900{ }^{\circ} \mathrm{C}$ for $3 \mathrm{~h}$ at constant temperature, the mass loss was used as the non-evaporable water content.

\subsubsection{Samples Microstructure Testing}

The samples were cored, broken or crushed, terminated hydration with anhydrous ethanol and at $60{ }^{\circ} \mathrm{C}$ in a vacuum dried for $4 \mathrm{~h}$. Samples with size of about $0.5-1 \mathrm{~cm}$ were selected for SEM-EDS test. The samples were grinded with agate mortar powder until they felt no granularness, and sifted by a $0.08 \mathrm{~mm}$ square-mesh sieve (particle size greater than $200 \mathrm{mesh}$ ). The following techniques were used to monitor the reactions, characterize the reaction products and analyze the microstructures:

(1) X-ray diffraction analysis: Using a Bruker D8 X-ray diffractometer (Bruker company, Germany) with $\mathrm{CuK} \alpha$ target radiation (scanning speed $=2^{\circ} / \mathrm{min}$; step size $=0.02^{\circ}$ ) to continuously scan specimens at $5^{\circ}$ to $70^{\circ}\left(2 \theta^{\circ}\right)$.

(2) FT-IR analysis: Adopting a Nicolet 6700 FT-IR spectrometer (Nicolet company, USA, spectral range $=400-4000 \mathrm{~cm}^{-1}$; resolution $=0.09 \mathrm{~cm}^{-1}$; dynamic adjustment $=130,000$ times $/ \mathrm{s}$ ) for the FT-IR test. 
(3) ${ }^{29}$ Si MAS-NMR analysis: Bruker Avance III 600M solid-state high-resolution nuclear magnetic resonance spectrometer (Bruker company), recording NMR spectra of Si at $39.72 \mathrm{MHz}$.

(4) SEM-EDS analysis: The samples surfaces are sputter coated with gold-palladium prior to imaging. Employing a field emission scanning electron microscope (SU8010; Hitachi; Tokyo, Japan) to observe surface morphology of the broken specimens and using an energy spectrometer to quantitatively analyze microelement content of the specimens. For chemical compositions of the reaction products, SEM-EDX point analyses were used, and 30 points per sample was tested [26].

\section{Results and Discussions}

\subsection{Paste Fluidity Analysis of the AACGS}

The fluidity of AACGS paste is mainly manifested as viscosity. The stronger the paste fluidity is, the better the initial expansion and slump of concrete prepared under identical conditions shall be. The paste fluidity of different samples is shown in Table 2. Paste fluidity rose as the slag content increases. In contrast to pure coal gangue samples (S0-12M2-36), samples with the slag content of $10 \%, 20 \%, 30 \%, 40 \%$ and $50 \%$ enjoyed a $7.10 \%, 14.49 \%, 17.61 \%, 20.65 \%$ and $23.55 \%$ increase in fluidity respectively. Kramar et al. [27] found that alkali-activated slag mortar $(180 \mathrm{~mm})$ possessed a greater fluidity than fly ash mortar $(152 \mathrm{~mm})$ and metakaolin mortar $(166 \mathrm{~mm})$ under the same conditions, which was mainly attributed to the following reasons: Slag had no regular crystals, thereby having a larger surface area than coal gangue. In addition, slag required less water than coal gangue. Therefore, the replacement of coal gangue by slag increased the liquid-solid ratio. It was revealed in Table 2 that the liquid-solid ratio makes a great influence on the fluidity of AACGS paste, and the larger the liquid-solid ratio, the greater the paste fluidity. Neither $\mathrm{NaOH}$ molar concentration nor $\mathrm{NaOH} / \mathrm{Na}{ }_{2} \mathrm{SiO}_{3}$ mass ratio was influential on paste fluidity. The paste fluidity was about $160 \mathrm{~mm}$. Furthermore, the paste fluidity of all alkali-activated samples was much greater than that of P.O 42.5 cement pastes.

\subsection{Compressive Strength of the AACGS}

Figure 2 reveals the compressive strength of the AACGS samples, the effects of slag content (Figure 2a), liquid-solid ratio (Figure $2 \mathrm{~b}$ ) and $\mathrm{NaOH}$ molar concentration (Figure 2c) were considered. As shown in Figure 2a, as the slag content increased, the compressive strength of AACGS samples increased at different ages. When the slag content was 50\%, the compressive strength of AACGS samples increased rate the most (55.98\%). The compressive strength of samples $1 \mathrm{~d}$ was about $50 \%$ of $3 \mathrm{~d}$ compressive strength, and the compressive strength of samples $3 \mathrm{~d}$ was about $85 \%$ of $28 \mathrm{~d}$ compressive strength, indicating the AACGS cementitious material samples could obtain higher early compressive strength. Figure 2a also shows the compressive strength of P.O 42.5 pure cement samples. It can be found that the appropriate quantity of slag could be used instead of coal gangue to make alkali-activated materials, and it could obtain a better compressive strength than that of P.O 42.5 Portland cement samples, especially the early compressive strength was obviously better than that of P.O 42.5 Portland cement samples.

Figure $2 \mathrm{~b}$ shows the compressive strength of samples at different liquid-solid ratios. Compressive strength, which was significantly influenced by water dosage and liquid-solid ratio of the mixture, linearly reduced with the increment of liquid-solid ratio. High liquid-solid ratio increased the ratio of liquid to solid in the mixture and improved the workability and uniformity of alkali-activated materials. However, larger-volume activator solutions tend to cause large porosity [28]. Furthermore, it can be seen from Section 3.1 that the liquid-solid ratio was the most influential factor on paste fluidity. The massive fluid mediums in alkali-activated polymers prevent the contact between alkaline activators and source materials [29].

Figure $2 \mathrm{c}$ reveals the compressive strength of samples under different $\mathrm{NaOH}$ molar concentration. It can be found that the compressive strength of $1 \mathrm{~d}, 3 \mathrm{~d}, 7 \mathrm{~d}$ and $28 \mathrm{~d}$ was the highest when the $\mathrm{NaOH}$ molar concentration was $12 \mathrm{M}, 14 \mathrm{M}, 16 \mathrm{M}$ and $16 \mathrm{M}$ respectively. The high $\mathrm{NH}$ molar concentration 
will accelerate the polymerization reaction, leading to premature condensation of $\mathrm{SiO}_{2}$ and $\mathrm{Al}_{2} \mathrm{O}_{3}$, thus reducing the early compressive strength [30]. However, with the increase of curing age, the high-alkalinity environment inside the AACGS system still exists, and the polymerization reaction will continue, leading to the increase of the later strength. In comparison with samples whose $\mathrm{NaOH}=8 \mathrm{M}$, samples with $10 \mathrm{M}, 12 \mathrm{M}, 14 \mathrm{M}$ and $16 \mathrm{M}$ enjoyed an increase in compressive strength by $3.55 \%, 4.30 \%$, $5.51 \%$ and $7.07 \%$ respectively, which indicates that $\mathrm{NaOH}$ molar concentration made little difference on $28 \mathrm{~d}$ compressive strength when the slag content was $30 \%$.

Figure 3 shows the compressive strength of samples at different $\mathrm{NaOH} / \mathrm{Na}_{2} \mathrm{SiO}_{3}$ mass ratios. It was found out that the maximum compressive strength value was obtained under the circumstance that the $\mathrm{NaOH} / \mathrm{Na}_{2} \mathrm{SiO}_{3}$ mass ratio valued 1:1.5. Both increased and decreased $\mathrm{NaOH}$ dosages decrease the compressive strength, reasons of which was below: Excessively low $\mathrm{NaOH}$ dosage generated the mixture insufficiently alkaline, thereby decreasing the polymerization rate and delaying the polymerization. If the $\mathrm{NaOH}$ dosage was excessively high, alkali-activated polymerization reacted rapidly, some coal gangue, slag and alkaline activators should fail to participate in the reaction and fill in the voids as residuals, thereby reducing the compressive strength.

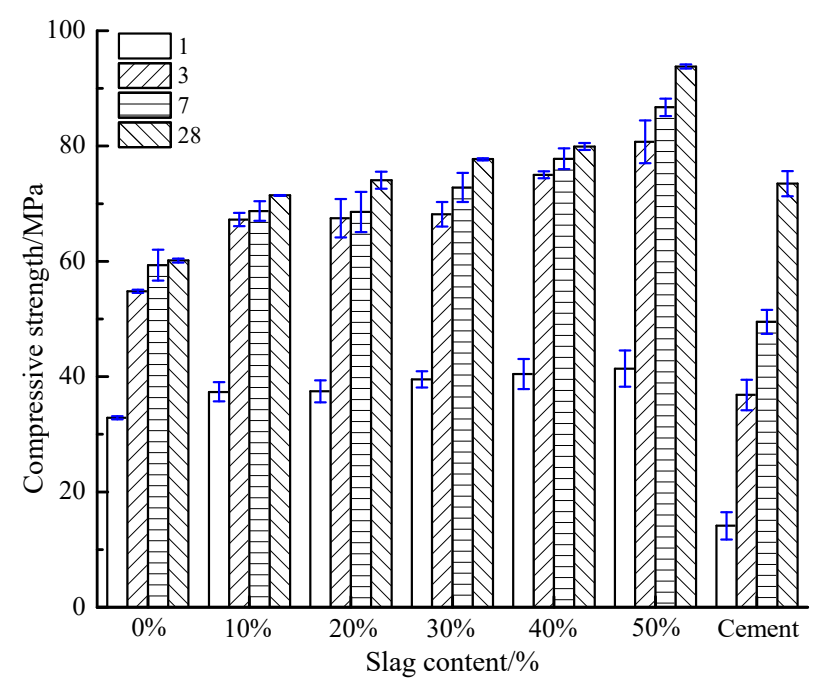

(a) Different slag content.

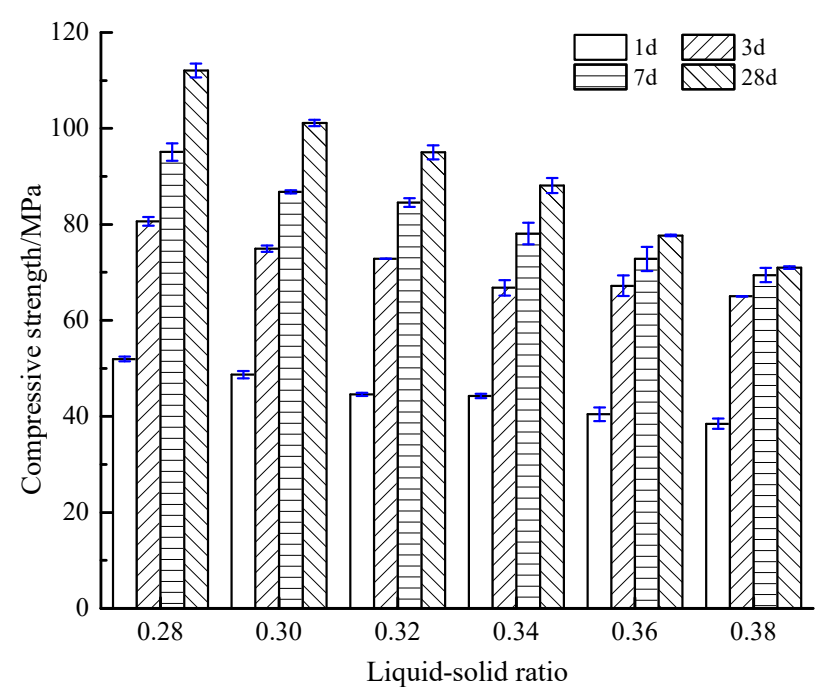

(b) Different liquid-solid ratio.

Figure 2. Cont. 


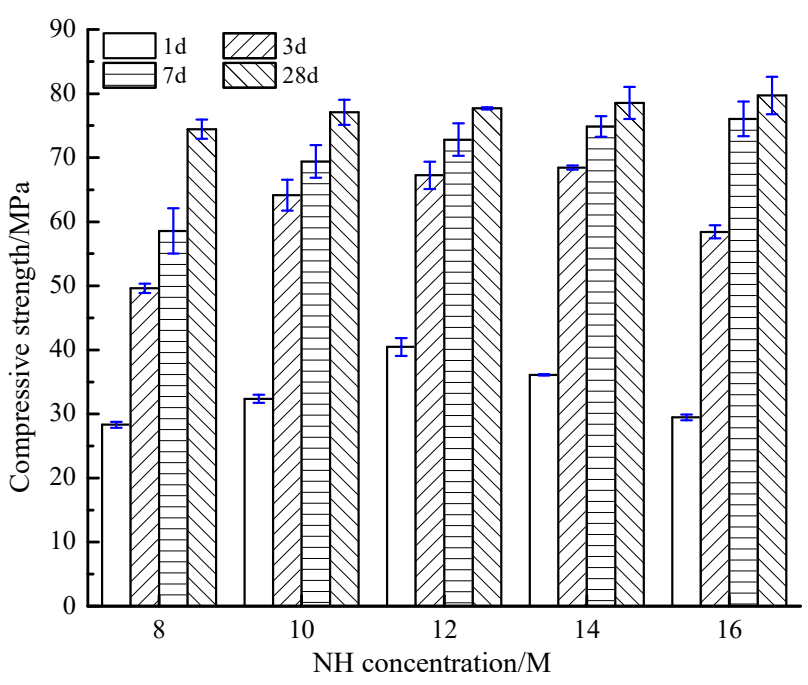

(c) Different $\mathrm{NaOH}$ molar concentration.

Figure 2. Compressive strength of AACGS samples. (a) Different slag content; (b) Different liquid-solid ratio; (c) Different $\mathrm{NaOH}$ molar concentration.

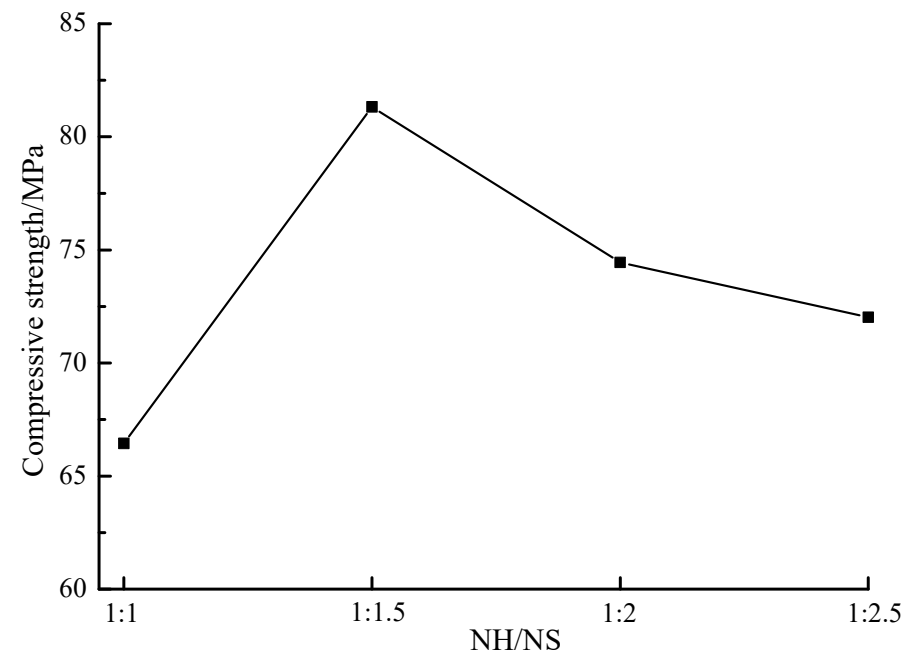

Figure 3. The compressive strength of samples with different $\mathrm{NaOH} / \mathrm{Na}_{2} \mathrm{SiO}_{3}$ mass ratio. $(\mathrm{NaOH}=8 \mathrm{M})$.

\subsection{Non-Evaporable Water Dosages of the AACGS}

The non-evaporable water dosage is not only related to the amount of hydration products, but also concerned with the type of hydration products. The non-evaporable water dosage of pure cement samples is proportional to the amount of C-(A)-S-H gels. In this paper, hydration products of AACGS polymers were mainly structurally disordered and highly cross-linked three-dimensional N-A-S-H gels, C-A-S-H gels and alumina-silica network polymers. Figure 4a shows the non-evaporable water dosage of AACGS samples with different slag contents. It was found out that the non-evaporable water dosage linearly rose as the slag content increased. In contrast to pure coal gangue samples, with the slag content of $10 \%, 20 \%, 30 \%, 40 \%$ and $50 \%$ enjoyed a $7.74 \%, 15.02 \%, 21.48 \%, 31.26 \%$ and $34.94 \%$ increase in non-evaporable water dosage respectively, indicating that slag content had a great impact on non-evaporable water dosage. Figure $4 \mathrm{~b}$ reveals the non-evaporable water dosage at different liquid-solid ratios. The non-evaporation water dosage first linearly increased with the liquid-solid ratio, and then slowly increased. 


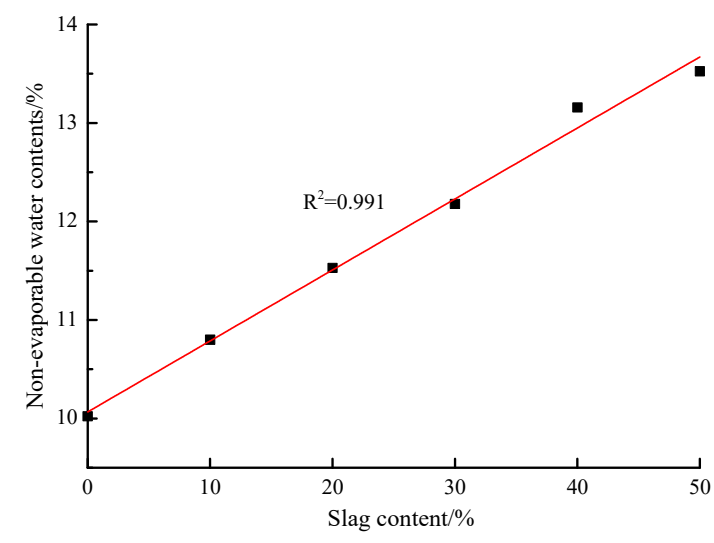

(a) Different slag content.

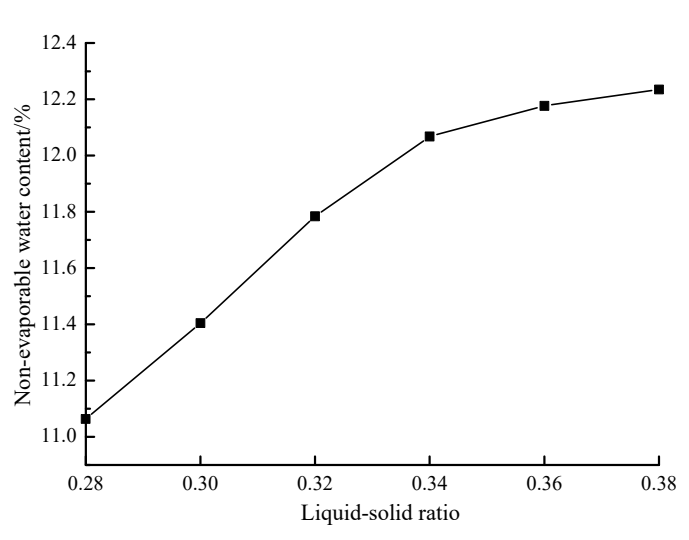

(b) Different liquid-solid ratio.

Figure 4. The non-evaporable water dosages of AACGS samples. (a) Different slag content; (b) Different liquid-solid ratio.

\subsection{XRD Analysis of the AACGS}

The main product of the AACGS samples is formed by intertwining the hydration products of the alkali-activated coal gangue and the alkali-activated slag. Figure 5 shows XRD patterns of AACGS samples with different slag contents, wider humps can be seen. The main characteristic peaks included $\mathrm{SiO}_{2}, \mathrm{CaAl}_{5} \mathrm{Si}_{20} \mathrm{O}_{10} \cdot 4 \mathrm{H}_{2} \mathrm{O}, \mathrm{NaAlSiO}{ }_{2} \cdot \mathrm{H}_{2} \mathrm{O}$ and $\mathrm{AlSi}_{2} \mathrm{O}_{5} \cdot \mathrm{xH}_{2} \mathrm{O}$, and the main crystalline phases were quartz and calcite. It can be seen from the figure that the cementitious materials contained a large amount of inert quartz that was not involved in chemical reactions. In other words, AACGS was a mixture of reactants and unreacted materials. Furthermore, the XRD diffraction pattern was analyzed by Jade, there were low-intensity diffraction peaks of calcium zeolite $\left(\mathrm{Ca}\left[\mathrm{Al}_{2} \mathrm{Si}_{3} \mathrm{O}_{10}\right] \cdot 3 \mathrm{H}_{2} \mathrm{O}\right)$ at $30^{\circ}$ to $40^{\circ}\left(2 \theta^{\circ}\right.$; PDF \#29-0809), reflecting the formation of a C-A-S-H gel phase. Moreover, the diffraction peak of $\mathrm{SiO} 2$ weakened and the diffraction peak of C-A-S-H gels were enhanced with increased slag content.

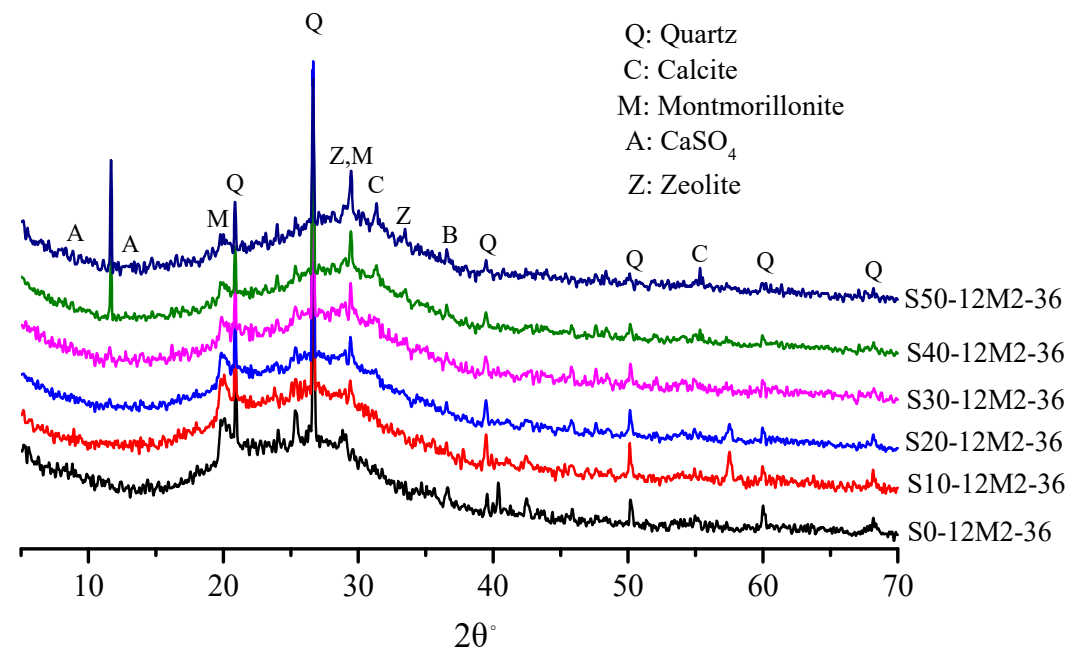

Figure 5. The XRD patterns of AACGS samples with different slag content.

Figure 6 shows XRD patterns of samples under different $\mathrm{NaOH} / \mathrm{Na}_{2} \mathrm{SiO}_{3}$ mass ratios. All the four samples had strong $\mathrm{SiO}_{2}$ and zeolite gel diffraction peaks and showed no difference in mineral composition. $\mathrm{SiO}_{2}$ with the $\mathrm{NaOH} / \mathrm{Na}_{2} \mathrm{SiO}_{3}$ mass ratio of 1.5 had the lowest diffraction peak intensity. In other words, active $\mathrm{SiO}_{2}$ had higher reactivity, which is in accordance with the law of compressive strength. The crystalline phase of the zeolite appears in both Figures 5 and 6, and the formation of the crystalline phase of the zeolite was positive for compressive strength of the samples. It has been found that the crystalline phase of the zeolite in the alkali-activated material is usually generated after 
mixing the raw material with the alkaline solution at high water dosage [31,32]. The study found that the amount of zeolite crystalline phase generated enhanced as the slag content increased.

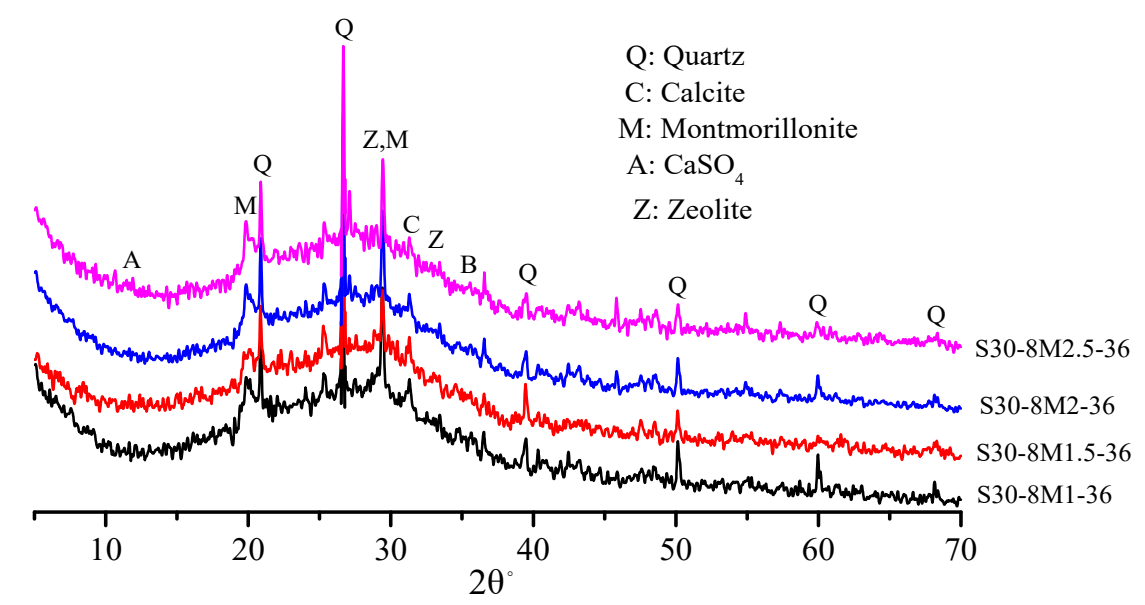

Figure 6. The XRD patterns of AACGS samples with different $\mathrm{NaOH} / \mathrm{Na}_{2} \mathrm{SiO}_{3}$ mass ratio.

\subsection{FT-IR Analysis of the AACGS}

Figure 7 shows the FT-IR spectra (spectral range $=400-4000 \mathrm{~cm}^{-1}$ ) of samples with the sample of S0-12M2-36 and S30-12M2-36. - $\mathrm{OH}$ bending vibration and $\mathrm{H}-\mathrm{O}-\mathrm{H}$ stretching vibration display absorption peaks at 3450 and $1650 \mathrm{~cm}^{-1}$ separately, which indicates that the samples contain chemically bound water [33]. Specifically, the absorption peaks appear at $3448.28 \mathrm{~cm}^{-1}, 1641.77 \mathrm{~cm}^{-1}, 3444.17 \mathrm{~cm}^{-1}$ and $1642.27 \mathrm{~cm}^{-1}$ in samples with the slag content of $0 \%$ and $30 \%$ respectively. $1429.86 \mathrm{~cm}^{-1}$ in Figure 7 is the absorption peak of the stretching vibration of $\mathrm{C}-\mathrm{O}$ and no obvious $\mathrm{C}-\mathrm{O}$ stretching vibration peak is detected in samples with the slag content of $0 \%$. Studies have shown that the stretching vibration of $\mathrm{C}-\mathrm{O}$ takes place at about $1440 \mathrm{~cm}^{-1}$ and relative absorption intensity of the peak increases with the increase in $\mathrm{CaO}$ dosage [34].

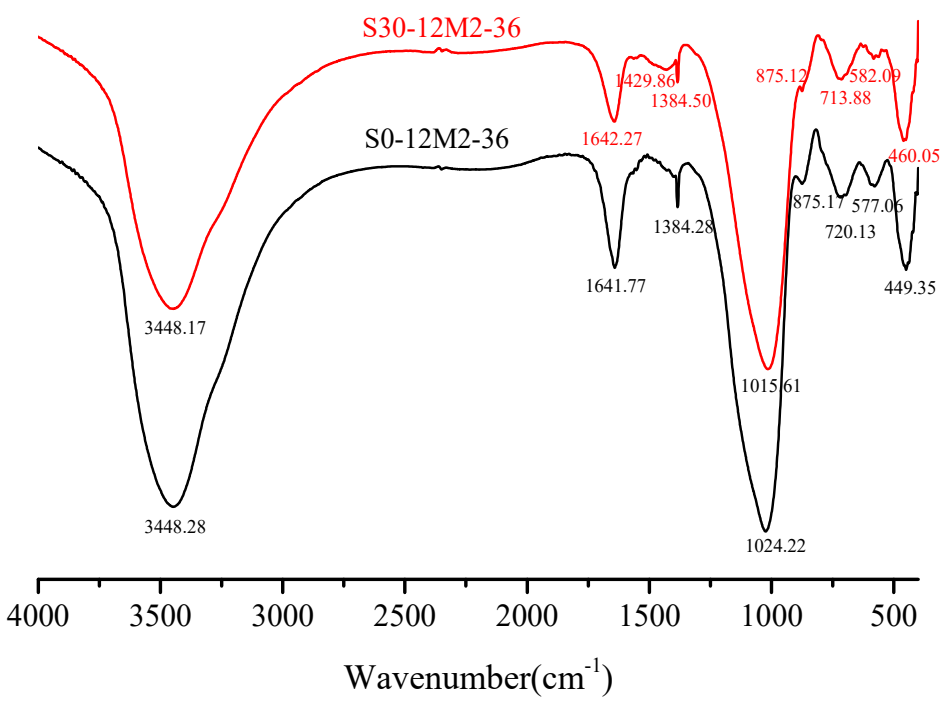

Figure 7. FTIR characterization of hardened paste with different slag contents.

Figure 8 shows the FTIR spectra (spectral range $=400-4000 \mathrm{~cm}^{-1}$ ) of samples with different $\mathrm{NaOH}$ molar concentration. It was obvious to observe the most powerful vibration band that produces corresponding to the Si-O bonds of N-A-S-H and C-(A)-S-H gels, and wave number of this band depends on the precursor reactants [15,35]. In all samples, a strong peak at about $1010 \mathrm{~cm}^{-1}$ indicates the inhomogeneous stretching vibration of $\mathrm{Si}-\mathrm{O}$ bond [14], indicating an important evidence of 
alkali-activated polymerization process [36]. Primary spectral bands of the FTIR spectra under $8 \mathrm{M}$, $10 \mathrm{M}, 12 \mathrm{M}, 14 \mathrm{M}$ and $16 \mathrm{M}$ were $1017.54 \mathrm{~cm}^{-1}, 1015.93 \mathrm{~cm}^{-1}, 1014.22 \mathrm{~cm}^{-1}, 1009.22 \mathrm{~cm}^{-1}$ and $1008.73 \mathrm{~cm}^{-1}$ correspondingly. In other words, absorption peak of the $\mathrm{Si}-\mathrm{O}$ bonds turned into low wave numbers with the increment of $\mathrm{NaOH}$ molar concentration, which suggests a lengthening of the $\mathrm{Si}-\mathrm{O}$ bond, a reduction in the bond angle. The regularly arranged chain structure of $\mathrm{Si}-\mathrm{O}$ bonds was broken and silicon was replaced by aluminum to form $\mathrm{Si-O}-\mathrm{Al}$ bonds in alkaline atmosphere [37]. In Figure 7 where the slag content was $30 \%$, the interactions between $\mathrm{SiO}_{2}$ and $\mathrm{Al}_{2} \mathrm{O}_{3}$ enhance with the increase in $\mathrm{CaO}$ dosage and absorption peak of the $\mathrm{Si}-\mathrm{O}$ bonds turned into low wave numbers with increase in slag content. Along with the formation of new materials, the spectral band from $710 \mathrm{~cm}^{-1}$ to $720 \mathrm{~cm}^{-1}$ was formed by the bending vibration of Si-O-Al bonds caused by $\mathrm{Al}$ (IV) replacement of Si. Spectra band at about $570 \mathrm{~cm}^{-1}$ in the FTIR spectra was due to the stretching vibration of $\mathrm{Si}-\mathrm{O}-\mathrm{Al}$ bonds while that at $450 \mathrm{~cm}^{-1}$ was attributed to the in-plane bending vibration of Si-O bonds [38].

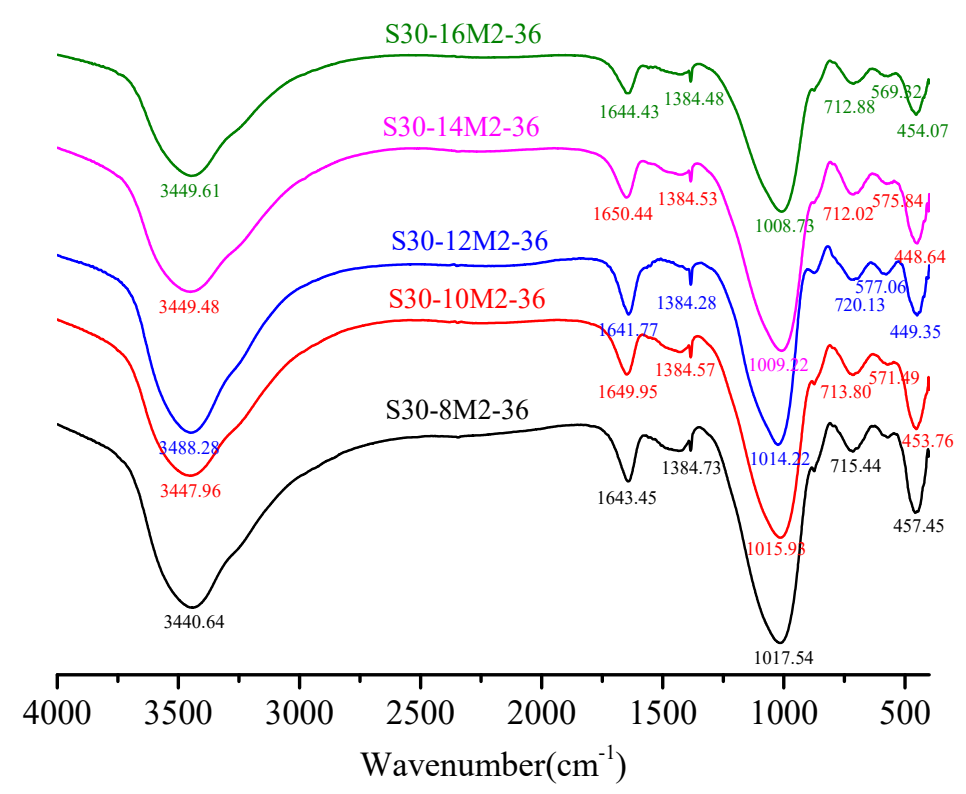

Figure 8. FTIR characterization of hardened paste with different $\mathrm{NaOH}$ molar concentration.

\subsection{Si MAS-NMR Analysis of the AACGS}

Figure 9 shows the ${ }^{29} \mathrm{Si}$ MAS-NMR spectra for the AACGS samples. Chemical displacements are usually explained according to disparate silicon $\mathrm{Q}^{\mathrm{n}}$ environments, where $n$ represents the number of bridging oxygens of other $\mathrm{Si}$ atoms connected to each $\mathrm{Si}\left(\mathrm{SiO}_{4}\right)$ tetrahedral unit [39]. NMR analysis provides information on the location of the ${ }^{29} \mathrm{Si}$ element, the coordination of the element and the degree of cross-linking of tetrahedrons to illustrate the polymerization process. The C-(A)-S-H gel mainly contains $\mathrm{Q}^{1}, \mathrm{Q}^{2}(1 \mathrm{Al})$ and $\mathrm{Q}^{2}$, which supports that $\mathrm{Al}$ can blend into the silicate chain without changing the structure in C-(A)-S-H. As the slag content increased, the dosage of active $\mathrm{SiO}_{2}$ decreased, resulting in the rise of $\mathrm{Ca} / \mathrm{Si}$ ratio, and the chemical displacement of silica polyhedron moved towards the direction of low field, indicating that the degree of polymerization of silicate structure in the hydration products of AACGS system increased, and the silicate structure system with high degree of polymerization led to higher strength development, which is in accordance with the results of compressive strength. 


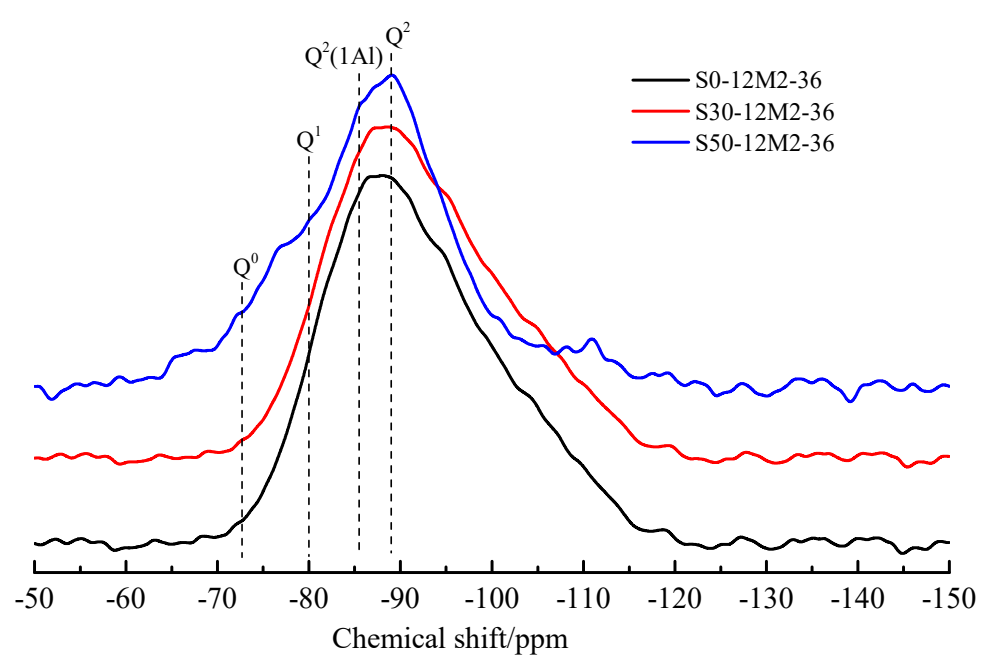

Figure 9. ${ }^{29} \mathrm{Si}$ MAS-NMR spectra for AACGS samples.

\subsection{SEM-EDS Analysis of the AACGS}

Figure 10 demonstrates SEM-EDS analysis of the broken surface of AACGS paste. Three groups with slag content of $0 \%, 30 \%$ and $50 \%$ were selected for SEM-EDS characterization in order to better understand the influence of slag. As the figures indicate, the difference between the three samples microstructures was evident. Five main features were observed in three samples: (1) Micro-cracks, (2) N-A-S-H gels, (3) C-(A)-S-H gels, (4) agglomerates, and (5) unreacted coal gangue particles. Alkali-activated coal gangue samples (Figure 10a) had relatively poor surface conditions, with a small quantity of gelatinous and flocculent products. As the slag content increased, flocculent gel crystals on the section surface increased. The main polymerization product of the alkali-activated coal gangue sample is N-A-S-H gels and agglomerates (amorphous alumino-silicate gels); and the main polymerization product of AACGS is N-A-S-H gels, C-(A)-S-H gels and agglomerates. When coal gangue is partially replaced by slag, the polymer gels are more compact. The two pozzolanic materials are well combined under the action of alkali, thereby increasing the compressive strength of the mixture. Furthermore, uniform micro-cracks were observed in the samples, which were mainly due to the drying shrinkage of alkali-activated samples [40]. Melo et al. [41], Cartwright et al. [42] and Mastali et al. [43] showed that the shrinkage value of alkali-activated materials was larger than that of pure cement materials.

The chemical reaction of alkali-activated coal gangue-slag materials mainly involved five atoms, such as $\mathrm{O}, \mathrm{Si}, \mathrm{Al}, \mathrm{Ca}$ and $\mathrm{Na}$. Therefore, EDS only extracts the percentage of these five atoms (At\%), and the average of the atomic percentage of each element in the three samples was calculated in Table 3. It is obvious that the $\mathrm{Ca} / \mathrm{Si}$ ratio and $(\mathrm{Ca}+\mathrm{Na}) /(\mathrm{Si}+\mathrm{Al})$ ratio of AACGS samples increased significantly with the increase of slag content. The external active $\mathrm{SiO}_{2}$ and $\mathrm{Al}_{2} \mathrm{O}_{3}$ reacted with $\mathrm{CaO}$ to produce $\mathrm{C}$-(A)-S-H gel with high $\mathrm{Ca} / \mathrm{Si}$ ratio when $\mathrm{Ca} / \mathrm{Si}$ was relatively high, which made the structure of slurry more compact and the macroscopic strength increased. Moreover, with the increase of slag content, the $\mathrm{Si} / \mathrm{Al}$ ratio of AACGS samples increased, $\mathrm{Si}$ and $\mathrm{Al}$ elements in coal gangue and slag also controlled the whole alkali excitation reaction process. With the increase of slag content, $\mathrm{Si} / \mathrm{Al}$ ratio increased, and higher $\mathrm{Si} / \mathrm{Al}$ ratio would lead to higher strength growth [44]. In other words, the increment of slag content result in the generation of $\mathrm{C}-(\mathrm{A})-\mathrm{S}-\mathrm{H}$ gels with higher $\mathrm{Ca} / \mathrm{Si}, \mathrm{Ca} / \mathrm{Al}$ and $\mathrm{Si} / \mathrm{Al}$ ratios, thereby improving the density and compressive strength of samples. 


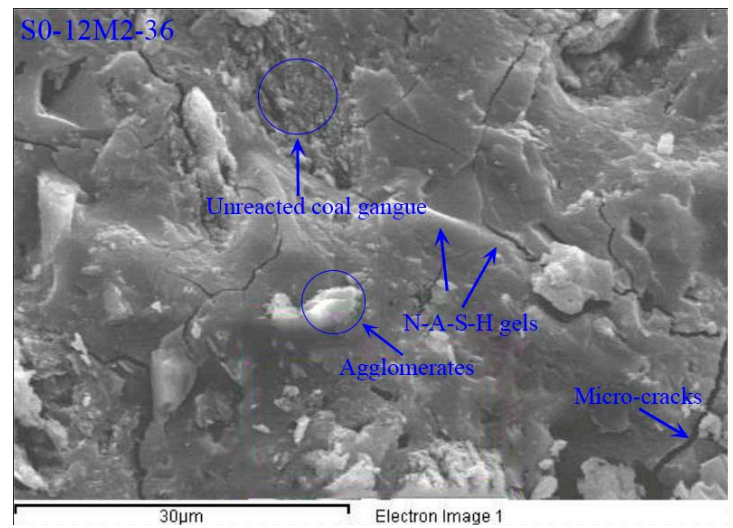

(a) S0-12M2-36

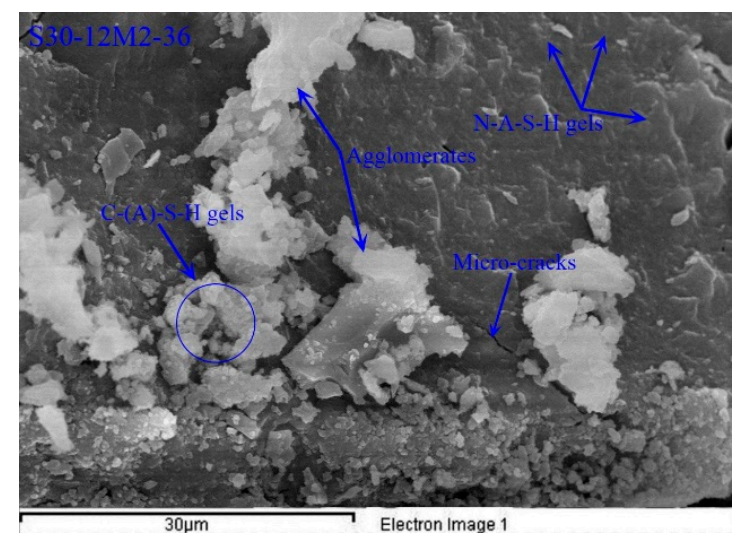

(b) S30-12M2-36

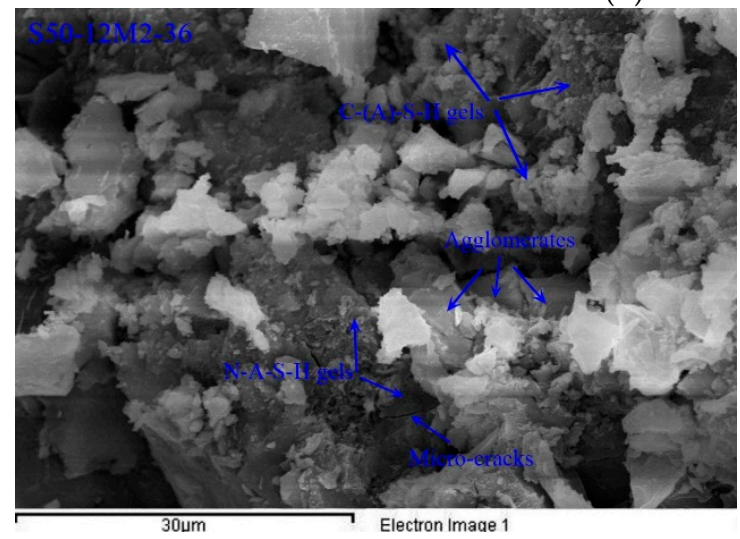

(c) S50-12M2-36.

Figure 10. SEM-EDS analysis of the broken surface of the AACGS paste. (a) S0-12M2-36; (b) S30-12M2-36; (c) S50-12M2-36.

Table 3. The average of the atomic percentage of each element in the three samples (At $\%)$.

\begin{tabular}{ccccccccc}
\hline $\mathbf{A t} \%$ & $\mathbf{S i}$ & $\mathbf{A l}$ & $\mathbf{C a}$ & $\mathbf{N a}$ & $\mathbf{O}$ & $\mathbf{C a} / \mathbf{S i}$ & $\mathbf{S i} / \mathbf{A l}$ & $\mathbf{( C a}+\mathbf{N a}) /(\mathbf{S i}+\mathbf{A l})$ \\
\hline S0-12M2-36 & 24.64 & 18.45 & 1.65 & 5.14 & 50.12 & 0.067 & 1.336 & 0.158 \\
S30-12M2-36 & 24.02 & 16.14 & 6.97 & 2.18 & 50.69 & 0.290 & 1.488 & 0.228 \\
S50-12M2-36 & 22.02 & 15.03 & 10.76 & 1.35 & 50.84 & 0.489 & 1.465 & 0.327 \\
\hline
\end{tabular}

\section{Reaction Mechanism}

Coal gangue belongs to silica-alumina material, which is decomposed by high temperature calcination to decompose $\mathrm{SiO}_{2}$ and $\mathrm{Al}_{2} \mathrm{O}_{3}$ with volcanic ash activity. The slag is a high calcium auxiliary cementing material with strong volcanic ash activity. Different from cement samples, AACGS materials were influenced by slag content, liquid-solid ratio, $\mathrm{NaOH}$ molar concentration and $\mathrm{NaOH} / \mathrm{Na}_{2} \mathrm{SiO}_{3}$ ratio in respect to the mechanic structure and microstructure significantly. Amorphous or metastable phases in silicon-aluminum materials chemically react with alkaline activators to form dense composites materials while crystalline phases fill internal voids of the materials [45]. Alkali-activated silica-alumina based materials are amorphous three-dimensional network structures [Q4(Al)] composed of $\mathrm{SiO} 4$ and $\mathrm{AlO} 4$ tetrahedrons that are linked by shared oxygen atoms [28].

In this paper, $\mathrm{Al}_{2} \mathrm{O}_{3}$ dosage of the coal gangue was up to $36.78 \% . \mathrm{Al}_{2} \mathrm{O}_{3}$, which was obtained through the dehydroxylation decomposition of kaolinite, and had enormous pozzolanic

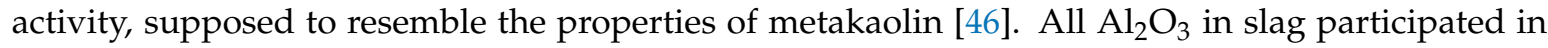
geopolymerization, as the slag content increased, the $\mathrm{Al}_{2} \mathrm{O}_{3}$ dosage in the mixture reaction precursor decreased. In the reaction process of AACGS materials, $\mathrm{Ca}^{2+}$ in the slag played an important role in the strength development. $-\mathrm{OH}$ attacked vitreous bodies of coal gangue and slag, leading to the 
fracture of vitreous Al-O-Si bond and the depolymerization and separation of the silica-aluminum phase. Furthermore, with the decrease of $\mathrm{Al}_{2} \mathrm{O}_{3}$ dosage, the alkali-activated geological polymerization process was divided into highly polymerized $\mathrm{AlO} 4$ and $\mathrm{SiO} 4$ units and a quasi-duplex structure rich in highly depolymerized $\mathrm{SiO} 4$ units. The atomic potential energy of $\mathrm{Si}^{4+}$ was twice in the tetracoordinate that of $\mathrm{Al}^{3+}$, exhibited stronger acidity and more easily polarized electrons on adjacent alkali metal oxide ions [47]. $\mathrm{Na}^{+}$and $\mathrm{Ca}^{2+}$ are used to balance the charge, $\mathrm{Ca}^{2+}$ has a stronger driving adsorption ability than $\mathrm{Na}^{+}$, and the high charge density of $\mathrm{Ca}^{2+}$ drives the precipitation of the crystal phase of the C-(A)-S-H gel [35], resulting in an increase in compressive strength.

Bernal et al. [48] found that low $\mathrm{MgO}$ dosage facilitated the integration of $\mathrm{Al}-\mathrm{O}$ tetrahedrons into the $\mathrm{C}-\mathrm{S}-\mathrm{H}$ chain. Therefore, the slight replacement of coal gangue by slag not only introduces $\mathrm{CaO}$, but also changes the dosage of $\mathrm{Al}_{2} \mathrm{O}_{3}$ and $\mathrm{MgO}$ in the mixture. The increase in slag content increased the dosage of $\mathrm{CaO}$ and $\mathrm{MgO}$ in the mixture, decreased the dosage of $\mathrm{Al}_{2} \mathrm{O}_{3}$, enhanced the reactivity of alkali reactions, decreased the chain length of $(\mathrm{N}, \mathrm{C})-(\mathrm{A})-\mathrm{S}-\mathrm{H}$ phases and increased the $\mathrm{Si} / \mathrm{Al}$ ratio, which was perfectly in compliance with the SEM-EDS analysis.

The results of XRD analysis showed that an amorphous silicon-aluminum network similar to the zeolite crystal phase was formed in the AACGS sample. The product of the S0-12M2-36 sample was zeolite-like alkali metal aluminosilicate (mainly sodium alumino-silicate). After incorporation of the slag, a calcium alumino-silicate product (C-(A)-S-H gel) appeared in the sample. The formation of three-dimensional amorphous polymer cementitious materials conduced to the binding performance of alkali-activated materials. The activation process of alkali-activated coal gangue is as follows: Active $\mathrm{SiO}_{2}$ and $\mathrm{Al}_{2} \mathrm{O}_{3}$ in coal gangue dissolve under the action of strong alkali, followed by the polycondensation of silicon aluminum. Sodium ion that is used to balance the charge is absorbed into silica-alumina gel phases.

In the alkali-activated coal gangue-slag reaction system, the coal gangue is the silica-aluminum material and the slag is the calcium-silica-aluminum material. $\mathrm{CaO}$ content in the alkali-activated coal gangue-slag reaction system increased with the increase of slag content. $\mathrm{CaO}$ reacts with different monomers (include silicate monomer and aluminate monomer) to form different reaction products. Some $\mathrm{CaO}$ reacts with silicate and aluminate to form the C-A-S-H gel, and some $\mathrm{CaO}$ reacts with silicate monomer to form the $\mathrm{C}-\mathrm{S}-\mathrm{H}$ gel. Some $\mathrm{CaO}$ reacted with the dissolved silicate and aluminate, which formed C-S-H gels. Some $\mathrm{Ca}^{2+}$ displaced $\mathrm{Na}^{+}$to form C-A-S-H gels. The reaction products of alkali-activated coal gangue-slag materials were C-(A)-S-H gels, N-A-S-H gels and silico-aluminate colloid, and the three gels interweave to form the network disordered structure of alkali-activated coal gangue-slag, which had good compatibility [2,49].

\section{Conclusions}

This paper explored the compressive strength and reaction mechanism of AACGS polymers and discovered that the strength and hydration were influenced by multiple factors, including the slag content, $\mathrm{NaOH}$ molar concentration, $\mathrm{NaOH} / \mathrm{Na}_{2} \mathrm{SiO}_{3}$ mass ratio and liquid-solid ratio. Specific conclusions drawn from this research are as follows:

(1) Liquid-solid ratio is the most influential factor on the fluidity and compressive strength of AACGS paste, followed by slag content. With the increase of liquid-solid ratio, the net paste fluidity of AACGS samples increased, but the compressive strength value decreased significantly. With the increase of slag content, the net paste fluidity and compressive strength of AACGS samples increased.

(2) $\mathrm{NaOH}$ molar concentration makes little difference to paste fluidity and $28 \mathrm{~d}$ compressive strength, high-molar concentration $\mathrm{NaOH}$ inhibits early polymerization of AACGS paste. The $\mathrm{NaOH} / \mathrm{Na}_{2} \mathrm{SiO}_{3}$ mass ratio also has little influence on paste fluidity of the samples.

(3) Main hydration products of AACGS materials include N-A-S-H gels, C-A-S-H gels and some other alkaline aluminosilicate gels. As the slag content increases, C-(A)-S-H gels with high $\mathrm{Ca} / \mathrm{Si}$, $\mathrm{Ca} / \mathrm{Al}$ and $\mathrm{Si} / \mathrm{Al}$ ratios are generated, thereby increasing the compactness of the AACGS materials. 
(4) The finding of this study demonstrated that adding a small amount of slag could improve the compressive strength of alkali-activated gangue obviously. The mechanical properties of AACGS have been obtained under different conditions, and the polymerization mechanism of AACGS has been studied in depth. The application of coal gangue materials was expanded in this paper, which provided factual basis for the preparation of polymer materials by using coal gangue. This study expanded the application of coal gangue in cementing materials, but its long-term drying shrinkage and durability need to be further studied.

Author Contributions: H.M., responsible for the overall design of the experiment and the writing of manuscripts; H.Z., responsible for the experimental funding and experimental guidance; C.Y., responsible for literature retrieval and experimental guidance; J.F., responsible for the production of charts; H.C., responsible for data collection; X.X., responsible for data analysis; T.W., responsible for data analysis.

Funding: This research was funded by the National Natural Science Foundation of China (NSFC, NO.51578539), Beijing Natural Science Foundation funded projects (NO.8164061), and the Open Research Project of State Key Laboratory of Coal Resources and Safe Mining, China University of Mining and Technology, (SKLCRSM16KFD07).

Conflicts of Interest: The authors declared that have no conflicts of interest to this work. We declare that we do not have any commercial or associative interest that represents a conflict of interest in connection with the work submitted. We declare that the funding agency does not affect the submission of manuscripts.

\section{References}

1. Gartner, E. Industrially interesting approaches to low- $\mathrm{CO}_{2}$ cement. Cem. Concr. Res. 2014, 34, 1489-1498. [CrossRef]

2. Rashad, A.M. Alkali-activated metakaolin: A short guide for civil engineer-an overview. Constr. Build. Mater. 2013, 41, 751-765. [CrossRef]

3. Huntzinger, D.N.; Eatmon, T.D. A life-cycle assessment of Portland cement manufacturing: Comparing the traditional process with alternative technologies. J. Clean. Prod. 2009, 17, 668-675. [CrossRef]

4. Luukkonen, T.; Abdollahnejad, Z.; Yliniemi, J.; Kinnunen, P.; Illikainen, M. One-part alkali-activated materials: A review. Cem. Concr. Res. 2018, 103, 21-34. [CrossRef]

5. Provis, J.L. Geopolymers and other alkali activated materials: Why, how, and what? Mater. Struct. 2014, 47, 11-25. [CrossRef]

6. Wardhono, A.; Gunasekara, C.; Law, D.W.; Setunge, S. Comparison of long term performance between alkali activated slag and fly ash geopolymer concretes. Constr. Build. Mater. 2017, 143, 272-279. [CrossRef]

7. Fernandez-Jimenez, A.M.; Lopez-Hombrados, C.; Palomo, A. Engineering properties of Alkali activated fly ash concrete. ACI Mater. J. 2006, 103, 106-112.

8. Law, D.W.; Adam, A.A.; Molyneaux, T.K.; Patnaikuni, I. Durability assessment of alkali activated slag (AAS) concrete. Mater. Struct. 2012, 45, 1425-1437. [CrossRef]

9. Zhang, J.; Shi, C.J.; Zhang, Z.H.; Ou, Z.H. Durability of alkali-activated materials in aggressive environments: A review on recent studies. Constr. Build. Mater. 2017, 152, 598-613. [CrossRef]

10. Saxena, S.K.; Kumar, M.; Singh, N.B. Fire resistant properties of alumino silicate geopolymer cement mortars. Mater. Today Proc. 2017, 4, 5605-5612. [CrossRef]

11. Lee, N.K.; Lee, H.K. Setting and mechanical properties of alkali-activated fly ash/slag concrete manufactured at room temperature. Constr. Build. Mater. 2013, 147, 1201-1209. [CrossRef]

12. Abdollahnejad, Z.; Luukkonen, T.; Mastali, M.; Giosue, C.; Favoni, O.; Ruello, M.L. Microstructural analysis and strength development of one-part alkali-activated slag/ceramic binders under different curing regimes. Waste Biomass Valorization 2019, 1-16. [CrossRef]

13. Duan, Y.; Wang, P. Early hydration of the material of alkali-activated coal gangue. J. Mater. Sci. Eng. 2008, 26, 511-515.

14. Li, N.; Shi, C.J.; Wang, Q.; Zhang, Z.H.; Ou, Z.H. Composition design and performance of alkali activated cements. Mater. Struct. 2017, 50, 177-187. [CrossRef]

15. Puertas, F.; Palacios, M.; Manzano, H.; Dolado, J.S.; Rico, A.; Rodríguez, J. A model for the C-A-S-H gel formed in alkali-activated slag cements. J. Eur. Ceram. Soc. 2011, 31, 2043-2056. [CrossRef] 
16. Pacheco-Torgal, F.; Castro-Gomes, J.; Jalali, S. Alkali-activated binders: A review: Part 1. Historical background, terminology, reaction mechanisms and hydration products. Constr. Build. Mater. 2008, 22, 1305-1314. [CrossRef]

17. Yi, C.; Ma, H.Q.; Zhu, H.G.; Dong, Z.C.; Su, Z.J.; Zhang, Y.T.; Chu, Z. Investigation on anti-carbonation performance of coal gangue coarse aggregate concrete. J. Build. Mater. 2017, 20, 134-140.

18. Moghadam, M.J.; Ajalloeian, R.; Hajiannia, A. Preparation and application of alkali-activated materials based on waste glass and coal gangue: A review. Constr. Build. Mater. 2019, 221, 84-98. [CrossRef]

19. Yi, C.; Ma, H.Q.; Zhu, H.G.; Li, W.J.; Xin, M.L.; Liu, Y.L.; Guo, Y.D. Study on chloride binding capability of coal gangue based cementitious materials. Constr. Build. Mater. 2018, 167, 649-656. [CrossRef]

20. Li, Y.; Yao, Y.; Liu, X.; Sun, H.; Ni, W. Improvement on pozzolanic reactivity of coal gangue by integrated thermal and chemical activative. Fuel 2013, 109, 527-533. [CrossRef]

21. Wan, H.; Gao, Z. Calcined coal gangue and clay shale for cementitious materials without clinker. Calcined Clay Sustain. Concr. 2015, 10, 169-177.

22. Geng, J.J.; Zhou, M.; Li, Y.X.; Chen, Y.C.; Han, Y.; Wan, S.; Zhou, X.; Hou, H.B. Comparison of red mud and coal gangue blended geopolymers synthesized through thermal activation and mechanical grinding preactivation. Constr. Build. Mater. 2017, 153, 185-192. [CrossRef]

23. Han, J.Y.; Song, X.Y.; Gao, Z.H. Excitation effect of soluble glass on composite system with calcined coal gangue and slag. Appl. Mech. Mater. 2012, 174-177, 30-34. [CrossRef]

24. Yi, C.; Ma, H.Q.; Chen, H.Y.; Wang, J.X.; Shi, J.; Li, Z.H.; Yu, M.K. Preparation and characterization of coal gangue geopolymers. Constr. Build. Mater. 2018, 187, 318-326.

25. Kumar, S.; Kumar, R.; Mehrotra, S.P. Influence of granulated blast furnace slag on the reaction, structure and properties of fly ash based geopolymer. J. Mater. Sci. 2010, 45, 607-615. [CrossRef]

26. Nedeljkovic, M.; Savija, B.; Zuo, Y.B.; Lukovic, M.; Ye, G. Effect of natural carbonation on the pore structure and elastic modulus of the alkali-activated fly ash and slag pastes. Constr. Build. Mater. 2018, 161, 687-704. [CrossRef]

27. Kramar, S.; Šajna, A.; Ducman, V. Assessment of alkali activated mortars based on different precursors with regard to their suitability for concrete repair. Constr. Build. Mater. 2016, 124, 937-944. [CrossRef]

28. Granizo, M.L.; Blanco-Varela, M.T.; Martínez-Ramírez, S. Alkali activation of metakaolins: Parameters affecting mechanical, structural and microstructural properties. J. Mater. Sci. 2007, 42, 2934-2943. [CrossRef]

29. Heah, C.Y.; Kamarudin, H.; Bakri, A.M.M.A.; Bnhussain, M.; Luqman, M.; Nizar, I.K. Study on solids-to-liquid and alkaline activator ratios on kaolin-based geopolymers. Constr. Build. Mater. 2012, 35, 912-922. [CrossRef]

30. Mastali, M.; Abdollahnejad, Z.; Pacheco-Torgal, F. Performance of waste based alkaline mortars submitted to accelerated carbon dioxide curing. Resour. Conserv. Recycl. 2018, 129, 12-19. [CrossRef]

31. Liew, Y.M.; Kamarudin, H.; Bakri, A.M.M.A.; Bnhussain, M.; Luqman, M.; Nizar, I.K. Optimization of solids-to-liquid and alkali activator ratios of calcined kaolin geopolymeric powder. Constr. Build. Mater. 2012, 37, 440-451. [CrossRef]

32. Zuhua, Z.; Xiao, Y.; Huajun, Z.; Yue, C. Role of water in the synthesis of calcined kaolin-based geopolymer. Appl. Clay Sci. 2009, 43, 218-223. [CrossRef]

33. Yu, P.; Kirkpatrick, R.J.; Poe, B.; Mcmillan, P.F.; Cong, X. Structure of calcium silicate hydrate (c-s-h): Near-, mid-, and far-infrared spectroscopy. J. Am. Ceram. Soc. 1999, 82, 742-748. [CrossRef]

34. He, J.; Yang, C.H. Influence of carbonation on microstructure of alkali-activated slag cement Pastes. J. Build. Mater. 2012, 15, 126-130.

35. Garcia-Lodeiro, I.; Fernández-Jiménez, A.; Palomo, A.; Macphee, D.E. Compatibility studies between $\mathrm{N}-\mathrm{A}-\mathrm{S}-\mathrm{H}$ and C-A-S-H gels. Study in the ternary diagram $\mathrm{Na}_{2} \mathrm{O}-\mathrm{CaO}-\mathrm{Al}_{2} \mathrm{O}_{3}-\mathrm{SiO}_{2}-\mathrm{H}_{2} \mathrm{O}$. Cem. Concr. Res. 2011, 41, 923-931. [CrossRef]

36. Phair, J.W.; Deventer, J.S.J.V. Effect of the silicate activator $\mathrm{pH}$ on the microstructural characteristics of waste-based geopolymers. Int. J. Miner. Process. 2002, 66, 121-143. [CrossRef]

37. Tippayasam, C.; Balyore, P.; Thavorniti, P.; Kamseu, E.; Leonelli, C.; Chindaprasirt, P. Potassium alkali concentration and heat treatment affected metakaolin-based geopolymer. Constr. Build. Mater. 2016, 104, 293-297. [CrossRef]

38. Lancellotti, I.; Catauro, M.; Ponzoni, C.; Bollino, F.; Leonelli, C. Inorganic polymers from alkali activation of metakaolin: Effect of setting and curing on structure. J. Solid State Chem. 2013, 200, 341-348. [CrossRef] 
39. Ye, H.; Radlińska, A. Shrinkage mechanisms of alkali-activated slag. Cem. Concr. Res. 2016, 88, 126-135. [CrossRef]

40. Ma, Y.; Ye, G. The shrinkage of alkali activated fly ash. Cem. Concr. Res. 2015, 68, 75-82. [CrossRef]

41. Neto, A.A.M.; Cincotto, M.A.; Repette, W. Drying and autogenous shrinkage of pastes and mortars with activated slag cement. Cem. Concr. Res. 2008, 38, 565-574. [CrossRef]

42. Cartwright, C.; Rajabipour, F.; Radlińska, A. Shrinkage characteristics of alkali-activated slag cements. J. Mater. Civil. Eng. 2014, 27, B4014007. [CrossRef]

43. Mastali, M.; Kinnunen, P.; Dalvand, A.; Firouz, R.M.; Illikainen, M. Drying shrinkage in alkali-activated binders-A critical review. Constr. Build. Mater. 2018, 190, 533-550. [CrossRef]

44. Sofi, M.; Deventer, J.S.J.V.; Mendis, P.A.; Lukey, G.C. Engineering properties of inorganic polymer concretes. Cem. Concr. Res. 2007, 37, 251-257. [CrossRef]

45. Wang, J.; Wu, X.; Wang, J.; Liu, C.; Lai, Y.; Hong, Z.; Zheng, J. Hydrothermal synthesis and characterization of alkali-activated slag-fly ash-metakaolin cementitious materials. Microporous Mesoporous Mater. 2012, 155, 186-191. [CrossRef]

46. Yang, C.; Yan, Y.; Ou, Z. Capability of cement paste binding chloride ions with metakaolin as admixture. Concrete 2010, 252, 1-4.

47. Weng, L.; Sagoe-Crentsil, K. Dissolution processes, hydrolysis and condensation reactions during geopolymer synthesis: Part I—Low Si/Al ratio systems. J. Mater. Sci. 2007, 42, 2997-3006. [CrossRef]

48. Bernal, S.A.; Nicolas, R.S.; Myers, R.J.; Gutiérrez, R.M.D.; Puertas, F.; Deventer, J.S.J.V. MgO dosage of slag controls phase evolution and structural changes induced by accelerated carbonation in alkali-activated binders. Cem. Concr. Res. 2014, 57, 33-43. [CrossRef]

49. Gomez-Zamorano, L.; Balonis, M.; Erdemli, B.; Neithalath, N.; Sant, G. C-(A)-S-H and N-A-S-H gels: Compositions and solubility data at $25^{\circ} \mathrm{C}$ and $50{ }^{\circ} \mathrm{C}$. J. Am. Ceram. Soc. 2017, 100, 2700-2711. [CrossRef]

(C) 2019 by the authors. Licensee MDPI, Basel, Switzerland. This article is an open access article distributed under the terms and conditions of the Creative Commons Attribution (CC BY) license (http://creativecommons.org/licenses/by/4.0/). 